\title{
The Luxury of Igniting Change by Giving Transforming Yourself While Transforming Others' Lives
}

\author{
Llamas, Rosa; Uth Thomsen, Thyra
}

Document Version

Accepted author manuscript

Published in:

Journal of Business Research

DOI:

10.1016/j.jbusres.2015.07.030

Publication date:

2016

\section{License \\ CC BY-NC-ND}

Citation for published version (APA):

Llamas, R., \& Uth Thomsen, T. (2016). The Luxury of Igniting Change by Giving: Transforming Yourself While Transforming Others' Lives. Journal of Business Research, 69(1), 166-176.

https://doi.org/10.1016/j.jbusres.2015.07.030

Link to publication in CBS Research Portal

\section{General rights}

Copyright and moral rights for the publications made accessible in the public portal are retained by the authors and/or other copyright owners and it is a condition of accessing publications that users recognise and abide by the legal requirements associated with these rights.

Take down policy

If you believe that this document breaches copyright please contact us (research.lib@cbs.dk) providing details, and we will remove access to the work immediately and investigate your claim. 


\section{The Luxury of Igniting Change by Giving: Transforming Yourself While Transforming Others' Lives Rosa Llamas and Thyra Uth Thomsen \\ Journal article (Post print version)}

This article was originally published in Journal of Business Research, Vol 69 Issue 1 , Pages 166-176. First published online 13 August २०15.

DOI: 10.1016/j.jbusres.2015.07.030

Uploaded to Research@CBS: Januar २016

(1) 2016. This manuscript version is made available under the CC-BY-NC-ND 4.0 license http://creativecommons.org/licenses/by-nc-nd/4.0/ 
The Luxury of Igniting Change by Giving: Transforming Yourself while Transforming others' Lives

\author{
Rosa Llamas, University of León \\ Thyra Uth Thomsen, Copenhagen Business School
}

Submission: November 2014

Revision: May 2015

Send correspondence to Rosa Llamas, Department of Marketing, School of Business, University of León. Campus de Vegazana, s/n 24007 León, Spain, telephone: +34 987291455, e-mail: rosa.llamas@ unileon.es; Thyra Uth Thomsen, Department of Marketing, Copenhagen Business School, Solbjerg Plads, 3, 2000 Frederiksberg C, Copenhagen, Denmark, telephone: +45 38152164, e-mail: tt.marktg@ cbs.dk. 


\title{
The Luxury of Igniting Change by Giving: Transforming Yourself while Transforming others' Lives
}

\begin{abstract}
This study investigates the phenomenon of luxury from a consumer perspective, by means of multisited phenomenological inquiry. The findings expand the pervasive view of luxury as accumulation of highly valued goods by offering a transformative perspective of luxury as transforming the life of distant others by giving them valuable philanthropic gifts and thereby ultimately transforming the self of the giver. The paper shows how giving away economic capital (money and time), social capital (networks and influence), and cultural capital (skills and knowledge) to non-related others can provide the giver with a sense of luxury in terms of pleasure, purpose and connection with humankind. Thus, the findings not only extend the traditional conceptualization of luxury from having to giving, but also challenge current conceptualizations of sharing out as non-reciprocal pro-social behavior by illustrating how 'the luxury of giving' relies on both pro-social and pro-ego consumption rationales, which implicitly include circular reciprocation.
\end{abstract}

Keywords: Luxury; Giving; Identity; Philanthropy; Self-transformations; Societal transformations. 


\section{The luxury of igniting change by giving: transforming yourself while transforming others' lives}

"What does one person give to another? He gives of himself, of the most precious he has, he gives of his life. This does not necessarily mean that he sacrifices his life for the other - but that he gives him of that which is alive in him; he gives him of his joy, of his interest, of his understanding, of his knowledge, of his humor, of his sadness - of all expressions and manifestations of that which is alive in him. In thus giving of his life, he enriches the other person, he enhances the other's sense of aliveness by enhancing his own sense of aliveness. He does not give in order to receive; giving is in itself exquisite joy. But in giving he cannot help bringing something to life in the other person, and this which is brought to life reflects back to him." - Erich Fromm

\section{Introduction}

Consumer research has traditionally linked the concept of luxury to conspicuous consumption as a way for the members of the upper class to demonstrate their wealth, power, and status through profligate spending (e.g., Dubois and Duquesne, 1993; Kastanakis and Balabanis, 2014; O’Cass and McEwen, 2004; Okonkwo, 2007; Truong, Simmons, and Kitchen, 2008; Veblen, 1994/1899). Past research has rarely defined luxury per se —few exceptions are Sombart (1922) and Sekora (1977), stating that luxury is anything beyond necessity. However, this definition takes point of departure in what luxury is not, rather than defining what luxury is. Attempts on defining luxury have since been made in specific contexts such as the context of luxury goods - in particular luxury brands. In this vein, Berry (1994, p. 41) states that "a luxury good is a widely desired (because not yet widely attained) good that is believed to be 'pleasing', and the general desirability of which is 
explained by it being a specific refinement, or qualitative aspect, of some universal generic need.” In line with this, Appadurai (1986, p. 38) offers a definition of luxury goods emphasizing their role as social markers, asserting that their "principal use is rhetorical and social, goods that are simply incarnated signs."

Goodwin, Ackerman, and Kiron (1997) assert that traces of luxury and symbolic consumption can be found throughout history; anthropological and archeological evidence suggest that such consumption is, perhaps, as old as human material culture itself. Following from this, the notions of luxury have been constructed differently in different systems - as a dynamic construct, always in motion (Kapferer, 2008), going through a metamorphose and renewing its appearance (Jäckel and Kochhan, 2000; Mortelmans, 2005). The once prevalent conspicuous, tangible and eye-catching concept of luxury that is linked to physical luxury goods and brands is evolving into the concept of luxury as intangible and subjective (Lipovetsky, 2003). This turning point marks the beginning of an interest into experiences of luxury as co-created phenomenon beyond the consumption of incarnated signs (Tynan, McKechnie, and Chhuon, 2010).

Past research has not yet fully explored luxury as a socially constructed phenomenon beyond the consumption of the "unnecessary." If luxury is more than that, then how can organizations accommodate consumers' needs for these other kinds of luxury? Especially, if they do not know what else luxury could be? Thus, the goal of the study was to take a step back to examine the phenomenology of luxury as seen by consumers. Based on this endeavor, the authors have learned that luxury has a plethora of meanings for consumers, besides the dominant understanding of luxury as the consumption of certain goods and brands. This paper presents one of the meanings that stood out due to its disruptive and counter-traditional take on luxury: luxury as philanthropic giving (economic, social, and cultural capital) to distant others, transforming the lives of others and self. This 
transformative perspective of luxury as transforming the life of distant others by giving them valuable philanthropic gifts and thereby ultimately transforming the self of the giver of luxury differs significantly from previous research on luxury in which having is at the core of the luxury concept (e.g., Megehee and Spake, 2012).

Drawing on the previous literature on luxury, sharing, and giving, the authors chart a link between sharing and philanthropy as luxuries in the postmodern society. The informants show that philanthropic giving may be perceived as a luxury when giving triggers significant transformations of non-related others (outward transformations), transforms the sense of self in relation to others (onward transformations), elevates the status of the self (upward transformations), and ultimately transforms the self (inner transformations). In the following sections the paper illuminates this consumer-based view of luxury as giving and its aftermath in terms of personal and societal transformations. The authors address the theoretical implications of the findings for the study of luxury, identity, status, philanthropic and prosocial behavior, well-being, and transformative consumer research. A discussion of the managerial implications of luxury as philanthropic giving follows, emphasizing the consequences of the findings for companies, non-profit organizations, educational institutions, and consumer society. These agents might re-think their mission by adopting a philanthropic approach as their raison-d'être. So, consumers and markets co-operate in the making of significant social change, fostering a transition from corporate social responsibility to collective social responsibility and thereby replacing industrial growth with life-sustaining society.

\section{Theoretical background}

\subsection{A classical approach to luxury}

The classical works of Berry (1994), Mandeville (1732), and Sombart (1922) investigate luxury in terms of changing attitudes about luxury and its benefits for society. The 
main body of research on luxury has since emerged in the specific context of goods. Even though this area is well-researched, the list of definitions of luxury applied to goods or brands goes on without consensus (Choi, 2003; Wiedmann, Hennigs, and Siebels, 2009). Goods and brands earn the luxury epithet when they have high price (e.g., Choi, 2003; Dubois and Paternault, 1995; Keller, 2009), excellent quality (e.g., Atwal and Williams, 2009; Choi, 2003; Christodoulides, Michaelidou, and Li, 2009), aesthetic beauty (e.g., Kapferer, 1997), pleasure (e.g., Berry, 1994), exclusivity, scarcity or uniqueness (e.g., Atwal and Williams, 2009; Chevalier and Mazzalovo, 2008; Christodoulides et al., 2009; Pantzalis, 1995), lack of utility and non-essentiality (e.g., Dubois and Paternault, 1995; Twitchell, 2002; Wiedmann et al., 2009), symbolic value (e.g., Keller, 2009; Vickers and Renand, 2003), and hedonism and pleasure (e.g., Christodoulides et al., 2009; Shukla, 2011; Vigneron and Johnson, 2004). In the same line, Megehee and Spake (2012, p. 1436) define "luxury" as "a configuration of a unique, aesthetic, functional, and expensive product-service experience.” Finally, Kapferer and Bastien (2012, p. 22) propose an integrative view when they assert that "luxury designates objects or services which are needlessly expensive: non necessary -one can live without it- no functional argument can ever justify their price, only the feeling of privilege made of rare quality, hedonistic experience, symbolic elevation and conspicuousness.”

Several studies have focused on identifying specific aspects of luxury as incarnated signs, that is, studies of luxury brands (Belk, Kimura, and Tanaka, 2007; Beverland, 2005; Dubois, Laurent, and Czellar, 2001; Dubois and Paternault, 1995; Freire, 2014; Groth and McDaniel, 1993; Phau and Pendergast, 2000; Vigneron and Jonson, 2004; Walley, Custance, Copley, and Perry, 2013), particular luxury goods conglomerates (e.g., LVMH: Cavender and Kincade, 2014), and specific product categories like vehicles (e.g., Hummer: Luedicke, Thompson, and Giesler, 2010; Schulz, 2006), or fashion (e.g., Fionda and Moore, 2009; Miller and Mills, 2012). Some have used a cross-cultural approach (e.g., Dubois and 
Duquesne, 1993; Tidwell and Dubois, 1996; Wong and Ahuvia, 1998), while others have focused on particular consumer behaviors like consuming counterfeits (e.g., Hoe, Hogg, and Hart, 2003; Nia and Zaichkowsky, 2000; Poddar, Foreman, Banerjee, and Ellen, 2012). Along these lines, some studies (e.g., Postrel, 2008) suggest that those belonging to the upper class are not so interested in luxury goods as status markers, but as pleasure providers.

\subsection{Luxury as having and transformations of self}

As the review of research on luxury illustrates, from an identity perspective, luxury has been mainly studied in terms of economic capital, which can be consumed conspicuously to signify consumers' social standing and identity (Appadurai, 1986; Douglas and Isherwood, 1979; Wiedmann, Hennigs, and Siebels, 2007). Hemetsberger, Hoppe, Matzler, Mühlbacher, and Pichler (2010) as well as Hoppe, Hemetsberger, Pichler, and Matzler (2009) refer to the self-transformative power of brands, seeing brands as enhancers of the transformation from the current self to the ideal self. Additionally, prior research (Bauer, von Wallpach, and Hemetsberger, 2011; Thomsen and Sørensen, 2006) documents that stereotypical products with strong symbolic values - like luxury brands- may aid consumers to cope with temporary or permanent transformations of consumer selves. They attribute their findings to the fact that some consumers experience liminality in terms of role uncertainty and discrepancies between current and ideal selves, which can be bridged by consuming and displaying easily recognizable goods that fit the hoped for identity (Noble and Walker, 1997; Schouten, 1991).

This conceptualization of the link between luxury and transformation of self rests on the notion of accumulation and display rather than donation of material goods. The findings of this study document that the link between luxury and transformation of self in the context of giving is of a different nature than in the context of having.

\subsection{Philanthropic giving and transformations of self and others}


Current conceptualizations of giving to non kin, also termed as "sharing out" (Belk, 2007, 2010, 2014), are non-reciprocal, since the giver does not hold an expectation of receiving anything in return from the recipient. Specifically, Benkler (2004) states that sharing is a 'nonreciprocal pro-social behavior.' Nevertheless, according to the data, a "proego" component may be also germane to the notion of sharing out since the giver may benefit from and be transformed by the act of giving in different ways. This idea resonates with Mauss's (1954) and Derrida's (1992) critical reflection about the existence of pure gifts. They argue that while pure gifts should be voluntary, disinterested, and spontaneous, involving no reciprocity or debt, they always involve some kind of self-interest -not least in terms of good feelings. In line with this argument, this study illuminates possible self-interest aspects of sharing, while recognizing its deeply rooted pro-social logic.

Sharing out may lead to some transformations of the giver -apart from changing in the eyes of the others. First of all, according to self-signaling and self-perception theory (Bem, 1967, 1972; Dhar and Wertenbroch, 2012; Lepper, Greene, and Nisbett, 1973), individuals come to know themselves in much the same way that they come to understand others by observing their own behavior. Thus, sharing out may cause consumers to change their self-identity. For example, they may infer from their behavior that they are "good" or "caring". In this vein, Belk and Llamas (2013) consider that sharing out may shape the selfidentity of the giver as "being helpful, generous, kind and thoughtful."

Second, philanthropic giving provides the giver with positive emotions (Dunn, Aknin, and Norton, 2008), which promote the giver's general well-being and happiness (Seligman, 2011). Specifically, prior research proposes that giving increases social and emotional bonds (Belk and Coon, 1993), which, in turn, can foster meaning as a sense of being "coherent, significant, directed, and belonging” (Schnell, 2009, p. 487). Since meaning, in terms of belonging and contributing to the common good, is a key source of happiness (Seligman, 
2011), giving ultimately changes the general well-being of the giver (cf. Aaker and Akutsu, 2009).

Finally, "sharing tends to be a communal act that links us to other people. It is not the only way in which we may connect with others, but it is a potentially powerful one that creates feelings of solidarity and bonding” (Belk, 2010, p. 717). This proposition means that sharing may involve transformations of the self and others by increasing their feeling of affiliation to a community. Sharing dilutes self-boundaries, invigorating consumers' gregarious sense of self. This idea is in line with prior research on gift giving, which documents that large gifts transform not only those who give but also their children and future generations (Scaife, McDonald, and Smyllie, 2011).

\section{Method}

In order to explore the phenomenon of luxury from a consumer perspective, a phenomenological research approach was applied. By adopting a qualitative approach the researcher gains an "inner experience of the study participants, to determine how meanings are formed through and in culture, and to discover rather than test variables" (Corbin and Strauss, 2008, p. 12). The meaning of things is derived from an interplay between cultural traditions and personalized meanings, which involves that meanings need to be contextualized and situated in relation to culturally shared knowledge (Thompson, Pollio, and Locander, 1994).

In particular, consumers' multilayered constructions of luxury were elicited by means of phenomenological interviews in a multisited empirical field covering four European capital cities: Stockholm (10 informants), London (10 informants), Berlin (10 informants), and Madrid (9 informants). Informants from different walks of life were recruited through the social and professional network of one of the researchers. The sample was deliberately 
diverse in terms of age and gender in order to amplify the possibility of finding varied stories (see Table 1 in the findings section). They were contacted in advance by e-mail, asking for their collaboration in the study. Since the objective was to explore the informants' personal perceptions of luxury, their preparation for the interview included collecting pictures (from magazines, newspapers, Internet, personal pictures, etc.) representing what luxury meant to them. Metaphor elicitation by using pictures may facilitate participants to overcome the taken-for-granted barrier and to embed their thoughts, feelings and experiences in elaborate narratives.

The interview would start with a small talk and a brief introduction about the research. Then, the informant would choose one of the pictures and would start talking about the content of the photograph. During the course of the interview, the role of the researcher was not to ask questions but to encourage informants to talk about their personal perceptions of luxury represented by the pictures they chose, expressing their feelings, experiences, meanings and symbolisms associated to the pictures, taking into account that "what is found in the picture is conditioned by the cultural knowledge the viewer brings to the viewing" (Ball and Smith, 1992, p. 18). Informants were encouraged to elaborate on their accounts by means of "floating prompts" (McCracken, 1988, p. 35). For example, repetition of the informants' last words with an interrogative tone, elicited thicker descriptions of the concepts gaining a deeper understanding of the topic. Furthermore, the interviewer prompted story telling by encouraging informants to describe actual experiences of their own notion of luxury rather than keeping the interviews on an abstract level. This "phenomenological" (Thompson, Locander, and Pollio, 1989) interviewer tactic allowed deep insights into consumer experiences to emerge with as little intrusion or direction as possible.

The interviews had a duration of between one and a half and three hours, were tape recorded, transcribed verbatim, and interpreted with an emic approach, following 
Thompson's hermeneutic framework (Thompson, 1997). The analysis process followed the methods of grounded theory, moving from open, to axial, to selective coding of data, with progressively deeper theoretical results at each step. The aim of this process was to get a holistic interpretation, identifying individual meanings of luxury, shared meanings that emerged across the narratives and pictures brought by several informants, and broader conceptual insights shared in society, filtered down through the informants. Immersion in the data set, revealed the polysemic nature of luxury. The term "polysemy" derives from modern hermeneutics, meaning that any unit can have more than one meaning (Alvesson and Sköldberg, 1994). This paper addresses the notion of luxury as philanthropic giving, which emerged as a significant theme in 11 of the 39 accounts (see list of informants in table 1). Surprised by this untraditional, philanthropic approach to luxury, the authors carried out several iterations of coding and depth analysis of these 11 accounts to delve into the meaning of luxury as giving.

\section{Findings: Luxury as giving something valuable to distant others}

The aim of this research was to explore the phenomenon of luxury nowadays as seen by consumers. Not only one meaning but many, stemmed from the data, disclosing the polysemic nature of luxury. Regarding to luxury as giving, an emic definition emerged from the data, as a voluntary act consisting of giving away something valuable and thereby making a significant, positive difference in the lives of distant others and the planet and, at the same time, transforming the self. Following, this article focuses on the main characteristics outlining this definition of luxury, that is, the valuable given (economic, cultural, and social capital), which leads the transformation of the recipients (non-related others, nature), and self, in different ways.

\subsection{The given: Valuable philanthropic gifts}


Giving away to others outside the boundaries of the family could include a wide range of activities such as giving a few coins to a beggar or a busker, donating blood/organs, adopting or sponsoring a child, making donations to different causes (e.g., non-profits, church, museums, art galleries, and Heritage), getting involved in volunteering, offering couchsurfing, and paying taxes. However, informants do not place all these examples under the luxury umbrella. The notion of luxury explored in this paper emerges from giving away something that the informants perceived to make a difference in the life of distant others, including future generations. High value is also germane to the pervasive idea of luxury but with a different scope. In this vein, Wiedmann et al. (2007) emphasize that the consumption of luxury goods entails acquiring goods that are valuable for both the individual and the reference group. So, while high value is part of the luxury equation, the classic approach rests upon the idea of accumulating highly valued goods, while according to the informants, their view of luxury does not only involve having but also giving highly valued resources. Therefore, the informants do not consider giving a few coins to a beggar a luxury, while they place making a remarkable contribution to the lives of those in need in the luxury scape. Table 1 illustrates the breadth of what our informants wanted to give, to whom they wanted to give, and which informant perceived the given as luxury.

Table 1 here.

As table 1 illustrates, this study broadens the scope of luxury to include not only traditional economic capital accounts of luxury but also social capital (networks and influence) and cultural capital (skills and knowledge). The article frames this type of giving as philanthropic giving, since "philanthropy covers not only traditional types of charitable giving, but also a range of ways in which people may show their general goodwill to society" (Hladká, 2009, p. 2). Based on the examples in table 1, the following sections elaborate on luxury as giving away these three types of capital. 


\subsubsection{Giving economic capital}

Veblen (1994/1899) argues that the consumption of luxury objects can signal differences in the economic capital of consumers. Instead, luxury as philanthropic giving rests upon giving away economic capital to others (e.g., Ragnar, M59, UK). However, the informants do not perceive every giveaway as a luxury; only substantive amounts of money, able to alleviate poverty and make a difference in the lives of those in need, ultimately make the giver happy and fulfilled as a reward. Nathan explains his view of luxury in terms of the parallel transformations experienced by the recipient and the giver, establishing a contrast between materialistic luxury versus the luxury of transforming others:

Some rich people are never satisfied. They have a big house but they want even a bigger house. They want two houses. They can't stop. I don't know... That's not luxury in my view. [...] Once you get to this stage where you can afford whatever you want, it would be too luxurious. Once you've got these things you sort of... anything else you want is different. Bill Gates donates to charity. They think 'I have enough so I can share it with people'. They get to this stage where they have got everything so they start giving back. Richard Branson, one of his companies gave all the profits to charity. Millions of pounds. Once you have got a car, a house, an island, it does not necessarily make you happy. Once you get there it does not make you any happier once your needs are fulfilled, you need fulfillment, you would probably get more pleasure making other people happy, to make a difference. You can go around helping people, donating different causes but you can't help everybody. It could be children, poor people, and your family. (Nathan, M37, UK)

Veblen's Theory of the Leisure Class (1994/1899) states that consumers emulate the conspicuous consumption patterns of those individuals at a higher point in the social hierarchy. As the account above illustrates, emulation can also be at play in inconspicuous consumption, since the notion of "noblesse oblige" may translate into the obligation to give once the giver has enough, thus emulating the consumption patterns of the upper class. Notably though, Nathan acknowledges this behavior as a personal luxury of fulfillment by making a change for others. 


\subsubsection{Giving cultural capital}

Bourdieu (1984) characterizes the cultural capital as composed of a set of socially rare and distinctive tastes, skills, knowledge and practices, which secures positions of status in the social hierarchy by exercising a mark of distinction. In this vein, one of the informants, Edita, volunteered in Ecuador, teaching English to very poor children who live in the jungle. She perceives sharing out her knowledge and skills with people in dire need as one of the greatest luxuries that she has experienced. When asked about what luxury meant to her, she said the following:

I went to Ecuador for four months, and that was a luxury. [...] I lived in the jungle, in the mountains and I taught the Ecuadorians kids English at a very poor school. [...] I think the worst thing for me would be at some point to be by myself. Living in a typical type of luxury people could think of and being by myself, maybe in a city in a nice expensive apartment and being by myself that would be terrible. You do not need all the money if you are not happy, if you are not enjoying yourself. [...] I would rather be in a rainforest not having much money or whatever but having the greatest fruit because they just come from the tree and being able to save the world by saving animals and bringing them back to rainforest or you are helping to save the rainforest and at the same time you will be helping the people because they will have a better standard of life. Just to be useful, to do something important. (Edita, F26, GE)

This informant contrasts her understanding of luxury with what she defines as a typical type of luxury, which she describes as having expensive possessions but no meaningful job -which would allow her to contribute to the lives of others, improving their standard of life. Instead, her idea of luxury relies on sharing cultural capital in terms of command of the English language and knowledge about wildlife preservation.

According to Bourdieu (1984), economic and cultural capital are inextricably related, since economic capital ensures buying capacity while cultural capital indicates a taste for choosing specific luxury items. Yet another link between economic and cultural capital lies in the ability to use economic capital to strengthen the cultural capital of others. For example, one of the informants dreams of providing the economic resources that allow the cultural capital of distant others to increase by endowing a gallery. 
I'll tell you another luxury. [...] I would also be happy to endow galleries and museums. Probably that is just vanity to get your name on. But I would not even mind doing it on anonymous basis but I would be quite happy to. I always liked galleries I always visited them. I even ended up working in one of them. It makes it easier for other people to see and enjoy. For example, in France last year they had the paintings of John Dunn, they had to raise a lot of money to pay special dues to get the cash in. If I was in a position to do so I would probably have bought it for them. (Christian, M61, UK)

\subsubsection{Giving social capital}

Social capital is "the aggregate of the actual or potential resources which are linked to possession of a durable network of more or less institutionalized relationships of mutual acquaintance and recognition" (Bourdieu, 1983, p. 249). As one of the informants explains, luxury is to have the social capital that is needed to give a voice to and empower the less fortunate. This informant selected a picture of three black boys sitting in a classroom, smiling. Mar explains as follows:

I've chosen this picture as representing a luxury because I would like to have the money or the ability to make a difference. Actually I think that the world would be much better if every single child had access to education and could read, write and go to school and I would really, really like to have the money or the ability to help and to make a difference. I think that it's our obligation to help those countries to have access to education and so every single child would be able at least to read and write and spend their childhood in school because it's where they should be and not working. There are many issues about poverty but making it possible for every child in the world to go to school I think that it would make a big, big difference. (Mar, F25, SP)

For this informant, luxury means to transform the lives of children via education, which she sees as a powerful transformational agent. She specifically points to individual transformations that -when accumulated-involve societal transformations. So, being influential and able to turn the spotlight toward those who do not have access to education and finally facilitating that access leads to the betterment of human life. On top of knowledge, the informants point to the social capital of fame and connection. For example, when asked about the meaning of luxury, Mar describes luxury as being able to make the kind of contribution that Angelina Jolie makes: 
Sometimes when you see actresses like Angelina Jolie -who are, not only playing Lara Croft-who are also UNESCO ambassadors and you see how much money they collect just because of her presence, just because of her being in that country, and they are able to collect a lot of money... I would like to be able to make that difference. It's not to have the money to pay for it, if I had the money I'd be glad to invest it there, but having the power to make people to draw their attention to that. These children need school, of course they need food too but... It's not about having the money to do it, it's about having the power, the influence to make people aware of these problems, of these situations. (Mar, F25, SP)

Here, Mar explains how celebrities like Angelina Jolie are willing to share not only their economic capital but also their social capital to transform the lives of others. Being able to emulate this philanthropic behavior would constitute a real luxury for this informant, which illustrates how sharing out social capital can be perceived as luxury.

The accounts above illustrate how luxury as giving differs in terms of giving economic/social/cultural capital respectively. The basic notion of luxury is, however, the same for all of these categories: a voluntary act consisting of giving away valuable resources and thereby making an impactful difference in the lives of non-related others and the planet and, at the same time, transforming the self.

\subsection{The recipients of the transformations}

According to Clark and Mills (1993), most people act as givers, contributing instinctively to the lives of others in close relationships like marriages and friendships, without keeping score about what they are giving and getting to/from them. In line with this ethos, the informants do not consider a luxury to contribute to the lives of the close ones. Instead, when consumers indulge in the luxury of contributing significantly to the lives of non-kin, they become part of a philanthropic milieu, enhancing their bonds and showing their goodwill to the members of their extended family, the human family. "Essentially, philanthropy is the mechanism through which people express their humanitarian impulses, and confirm their membership of a wider society" (Lloyd, 2004, p. 11). Accordingly, the 
informants indicate both non-related others, nature, and self as recipients of the transformations that luxury as giving brings about.

\subsubsection{Non-related others}

According to the accounts, the act of giving must have a substantial impact on the common good in order to be perceived as luxury, for example, in terms of raising the level of goodness for someone unrelated to the giver. In this regard, several of the narratives describe the luxury of giving as related to improving the lives of other human beings, especially children. For example Gretel finds a luxury to be able to perform a permanent transformation in the life of a girl by adopting her:

I also find it a luxury to adopt a girl. [...] Even if I had the time [to have another baby], I would like to adopt a girl, because there are many girls in some countries in Africa or in India who are treated badly and they also suffer discrimination compared to boys. [...] My uncle has just adopted two Ethiopian sisters. (Gretel, F38, GE)

The accounts related to children range from luxury as investing time and money in adopting a child, just like Gretel's uncle did, to luxury as spending time and/or money on children in wretched living conditions. Eva considers the latter to be a luxury:

I think it is also luxury to be able to spend time with children [...] I wish I could find a way to offer my services to the society, taking care of children who have no place to go or parents who are not functioning, for a while as long as they cannot live at home. (Eva, F50, SW)

Finally, a third way of describing luxury as giving to children is to donate and work for children's causes using education as the catalyst for transformation (Mar, F25, SP).

While most informants link the luxury of philanthropic giving to children as recipients, they also mention other beneficiaries. However, unfortunate circumstances are a common factor in all the beneficiaries, that is, poor people (Nathan, M37, UK), the elderly (Ragnar, M59, SW), ill people (Ragnar, M59, SW), or people in need beyond their resources (Christian, M61, UK). 


\subsubsection{Nature}

On top of making a difference to others, some informants describe how the common good could also consist of preserving the planet, contributing to the lives of other living beings and future generations. For example, David has bought a car that is slower and more expensive than other cars he could have bought. However, David justifies the extra cost because it is a luxury to him to be able to drive a "green" car which preserves the nature.

My new luxury is that I just bought a new car. I bought the Prius [...] It is an ecological car. [...] I could buy a car for 5000 pounds. This one costs 18000, so the rest was about luxury, about aspiration. [...] It is not price. You move to a different aspiration area. You suddenly start buying what is 'green'. I care about the environment now. I am still driving and still burning fuel, but now burning is much less. [...] It was more expensive than the carbonized car. But I am already very happy about it because I am making a positive effort for the environment. [...] The wealthier people have more choice and they want to feel good about their purchase. Not everybody but I do. I care about the environment. (David, M42, UK)

Likewise, in Henrike's view, to be able to buy organic food is a luxury -not just in

order to be healthy but also to contribute to the future well-being of the planet.

[Another luxury that I have is that] I buy all my food organic in ecoshops. [...] I am a really conscious consumer. [...] I am really keen [...] to have good healthy food, but the other thing is to have good development of nature and everything, because I do not want to use everything and give my son and the future generations a rotten world. I would like to have more eco farmers and people who look what they are doing to take care of what we have. Our planet is where we live and we will not have another one, we have to be conscious of what we are doing with it, this is really important for me. (Henrike, F25, GE)

While recent studies question the compatibility of sustainable practices and the category of luxury products (Achabou and Dekhili, 2013) these accounts show how consuming sustainable can be perceived as a luxury per se, since this luxury involves investing economic resources in making a positive effort for the environment. According to Achabou and Dekhili (ibid.), product quality overcomes sustainability in relation to the acquisition of luxury products. However, as illustrated above, the performance of sustainable 
consumption practices can be perceived as a luxury in its own terms - even if the consumer does not consider the consumed a luxury.

\subsubsection{Self}

All the informants included in this study conceptualize giving as a personal luxury. Consequently, they initially recognize giving away either economic, cultural, and/or social capital as something of value to them personally and thus not intended to be solely pro-social. Giving holds the potential of not only transforming others but also the self, and in that respect also a pro-ego behavior. For example, the informants acknowledge that allowing themselves the luxury of philanthropic giving would ultimately have an impact on their own lives. Informants look forward to fulfillment (e.g. Nathan, M37, UK), a better world for their children (e.g., Henrike, F25, GE), or -as the following account describes-feeling useful:

[Another luxury for me is that] I would like to work in something to help people to feel better or make a better quality of life for them. [...] Something that has to do with charity or something where you really see results of helping people or doing something, you know. You feel useful by helping people in some way. (Kajsa, F29, $S W)$

Likewise, for example, some informants explicitly refer to specific outcomes in store for the giver in terms of, for example, recognition and satisfaction:

At this time in my life I don't find a luxury to have an expensive car or a yacht, I wouldn't be satisfied. Instead, I would prefer to donate this money to an institution. I'm not one of those people who want a monument or a huge nameplate but eventually, I'd like a mention in a book or in any other place saying that I've made a good contribution. It might be a school, or a hospital, or a home for elderly people. Then I'd be more satisfied. (Ragnar, M59, SW)

Further, some of the mentioned pro-ego aspects of sharing are its ability to support the creation of a sense of self, and its ability to bring about a state of well-being. As for selfextension (Belk, 1988), the informants refer to an extended self in terms of being a conscious 
consumer (Henrike, F25, GE), being an atypical luxury consumer (Edita, F26, GE), or being someone who gets recognition for making a good contribution (Ragnar, M59, SW).

In terms of well-being, the informants point to both positive emotions and a meaningful life. Positive emotions include, for example, feeling very happy and good (David, M42, UK), feeling love and loved (Edita, F26, GE), getting pleasure (Nathan, M37, UK), and feeling useful (Kajsa, F29, SW).

Further, the informants consider a meaningful life as an important outcome of giving, described as, for example, fulfillment (Nathan, M37, UK) and as making a difference (which proves to be essential for all informants). In the data, the notion of luxury is a life imbued with purpose, associated with the fruitfulness of giving, by bettering the lives of others. Together, positive emotions and a meaningful life are two important components of overall happiness and well-being (Seligman, 2011) and thus the luxury of giving holds strong promises of self-directed benefits.

The luxury of giving does not involve dyadic reciprocity, since the giver presents the philanthropic gift without any expectation of return from the unrelated recipients. Nevertheless, the luxury of giving cannot be described as truly altruistic since, as shown in the data, self-directed benefits are inextricably linked to the luxury of sharing out. However, these pro-ego outcomes of sharing out are largely non-contingent on reactions from the actual recipients of what is given but instead are linked to the giver's idea of making a difference. Within this study, acts of kindness bring about change in the common good, which spreads and ultimately reflects back on the giver as part of mankind, what the authors would coin “circular reciprocity" at play.

\section{Discussion}


This paper extends conventional understandings of the notion of luxury based on having, by placing luxury in the realm of transforming self and others by giving. Here, luxury does not necessarily mean having and displaying expensive brands or extravagant experiences, instead, according to the informants, luxury can also mean being able to make significant improvements in the lives of distant others by providing them with economic, cultural, and/or social capital and, simultaneously, transforming the self of the giver. In this vein, the present study offers new and disruptive insights to the luxury literature from a sociological perspective, urging a multilayered redefinition of the construct.

In addition, the endeavor to disentangle the rather unknown phenomenon of "luxury as philanthropic giving," adds to current discussions about the conventional understandings of the notion of sharing as "nonreciprocal pro-social behavior" (Benkler, 2004) by highlighting how sharing out can also entail pro-ego components and aspects of circular reciprocity. As illustrated by this study, certain types of sharing can be perceived as a personal luxury, thus acknowledging the interlinkages between the well-being and transformation of others with the well-being and transformation of self as essential parts of sharing out.

This study shows that these transformative components of the luxury of giving take place in a plurality of levels of others and self. First of all, substantive contributions to the lives of distant others lead to outward transformations and, ultimately, due to a ripple effect, to societal transformations. Second, inward transformations may occur due to the rise of a fulfilled and whole self in the aftermath of engaging in meaningful and pleasurable philanthropic giving. Third, by linking the self to the lives of others, the relationship between non-related givers and receivers is strengthened and the membership to humankind as the first and foremost community is upgraded, yielding onward transformations of the philanthropic giver via a gregarious sense of self. Finally, similar to the status-elevating 
potential of conspicuous consumption, the luxury of giving can promote upward transformations in the social status of the giver by means of conspicuous generosity. The paper elaborates on the four types of transformations below.

\subsection{Outward transformations: Transforming distant others}

In an individualistic society where personal goals are encouraged, one of the notions of luxury takes a turn toward universalism, in a quest for the common good and finding meaning and happiness in the process. The keywords outlining the personal meaning of luxury provided by the informants are non-possessiveness, generosity and friendliness, which contrast with the personality traits attributed to materialism: possessiveness, nongenerosity, and envy (Belk, 1985). This view of luxury falls into the category of what Sombart (1922) names as "idealistic or altruistic luxury" as opposed to "materialist, egoistic luxury," challenging the common association between luxury and materialism.

The pervasive notion of luxury aligns with the core values of the egocentric society, that is, "safety, comfort, middleworld pleasure, and enhancement of socioeconomic status" which involves accumulation of wealth, leading finally to "boredom, addiction, alienation, and meaninglessness" (Plotkin, 2008, p. 46-47). This egocentric society celebrates individualistic values at the expense of consumers' connections with their peers, which is the first and foremost community to which they belong. The feeling of other-orientedness and belongingness lies at the root of the human nature but the individualistic and egocentric society has suppressed this sense of association - or dramatically limited these ties to close ones.

This study documents that some consumers perceive making significant contributions to the lives of others and experiencing self-transformations while doing so, as a luxury. Thus, they show a quest for significant macro transformations by providing transformative agents 
like education, shelter, affection, art, culture, care, knowledge, and money. They are able to yield more cultured selves, educated selves, healthy selves, loved selves, happier selves, selves with a better-looking future and a better-preserved planet. These consumers leave behind an egocentric society (materialistic, anthropocentric, competition based, class stratified, violence prone, and unsustainable) and move into a soulcentric or even an ecocentric society (imaginative, ecocentric, cooperation based, just, compassionate, and sustainable) (cf. Plotkin, 2008) while indulging in the luxury of giving.

\subsection{Inward transformations: A desired self}

Just like luxury brands have the power of transforming an ordinary self into a sophisticated and glamorous one, the findings illustrate how the luxury of performing significant acts of altruism holds the power to transform an ordinary self into a desired self. The luxury of initiating substantive transformations in non-kin by giving away economic, cultural, and/or social capital can bring about inward transformations and release a renewed self: for example, an altruistic, socially responsible, purposeful, fulfilled, and joyful self.

According to Thompson and Hirschman (1995, p. 151), "consumption serves to produce a desired self through the images and styles conveyed through one's possessions." The findings extend this proposition about the desired self by adding actions as conveyors of identity. In particular, the informants identify engaging in purposive activities -like indulging in the luxury of giving valuable resources to improve the welfare of non-related others-as a way of creating a desired self. Their personal views of luxury reveal that making a significant impact in the lives of others constitutes an avenue for self-expression, triggering a shift in their own identity. This notion is in line with self-signaling theory, according to which people infer what kind of person they are from their consumption practices (Dhar and Wertenbroch, 2012), including their sharing out behavior (Belk and Llamas, 2013). 
This burgeoning self emerges in a social context, so the others unconsciously, perform the role of helpers in this process of identity transformation. So, in the narratives, the distant others act as the ink enabling consumers to write their story. According to Kauppinen (2013), consumers perceive as meaningful those activities which "move our life story forward in the direction of making a difference in the world." In other words, meaning comes from transcending the ego, by serving a cause bigger than ourselves (Seligman, 2011).

Additionally, the paper illustrates how the luxury of giving can bring about inward transformations by providing the giver with joyous feelings. This emotional consequence of doing good has been documented in prior research on charitable behavior regardless of whether the donor acts according to a social norm or according to a specific (pro-social, altruistic) self-image (Bekkers and Wiepking, 2007). The joys of charitable giving have been studied under labels like "empathic joy" (Batson and Shaw, 1991), "warm glow", or the "joy of giving" (Andreoni, 1989). Giving provides the giver with feelings of happiness, which may raise personal happiness more than spending the same amount of money on own consumption (Aknin, Barrington-Leigh, Dunn, Helliwell, Burns, Biswas-Diener, Kemeza, Nyende, Ashton-James, and Norton, 2013). This outcome is in line with research on charitable donations in which the pro-ego effects of giving are a well-documented phenomenon (Ye, Teng, Yu, and Wang, 2015). Notably, this result reaffirms the abovementioned idea that indulging in the luxury of giving is not altogether devoid of the pleasures and positive feelings commonly associated with the accumulation or consumption of luxury goods (e.g., Kapferer, 1997).

\subsection{Onward transformations: A gregarious self}

Consumer research literature addresses giving in all its versions, whether monadic, dyadic or systemic gift giving, as an enhancer of relationships (with self or others). Gifts can engender an expression of love and caring for another person or group of persons (Cheal, 
1988), but they can also be used to express cultural values and social connections (Belk Wallendorf, and Sherry, 1989). Giving increases the feelings of interdependence and belonging (Lyubomirsky, 2008), while supporting identity projects (Belk, 2010; Sherry, McGrath, and Levy, 1995).

In the same vein, philanthropic giving reinforces the link with others, transcending the traditional, immediate circles (kinship, friendship, romance) experiencing more permeable and fluid self-other differentiation boundaries. However, unlike traditional gift giving, philanthropic giving does not strengthen the link with a particular recipient, but serves a higher purpose of setting a link with the whole community -humankind, which is the primary natural community. Hence, opening up self-boundaries by giving creates a sense of communion with unrelated others and the world, leading to a gregarious sense of self.

The instinct for human connection inherently resides in human nature and goes beyond family ties. However, perhaps the individualistic society has reduced consumers' sense of common humanity, limiting their relations to a micro scale. So, some contemporary consumers experience interconnectedness at a large scale by perceiving it a luxury to make valuable contributions to the lives of non-related others. Notably, to these consumers othersinterest and self-interest are not mutually exclusive but a compatible and desirable tandem.

\subsection{Upward transformations: The status-elevated self}

The traditional understanding of luxury is tightly linked to the pursuit of status, and luxury as philanthropic giving is not utterly devoid of this notion. Some of the informants mention acknowledgement as an expected outcome of the luxury of performing significant acts of altruism. Hence, luxury as giving holds the ability to provide symbolic capital that can add to the giver's identity construction and social status. Therefore, in the realm of distinction, traditional logos of luxury brands coexist with philanthropic displays. In this line, 
Veblen (1994/1899) considers that philanthropy involves a public display of wealth aimed at securing esteem, and consequently, he places this exhibition in the sphere of conspicuous consumption. More recently, Toynbee and Walker (2008) take an anti-philanthropy position, asserting that philanthropy is "mere ostentation," "a passport to the in-crowd," and "another way of exerting power and control." Indulging in the luxury of doing good may turn into "badges of luxury" especially due to the blurred lines of public/private spheres in the digital age. Similarly, previous research shows how conspicuous philanthropic displays enhance the status and prestige of the giver (Boone, 1998; Hardy and Van Vugt, 2006; Roberts, 1998), while Winterich, Mittal, and Aquino (2013) find a strong link between recognition and charitable behavior. So, making a difference in the lives of others may be rooted in selfinterest, acting as a catalyst for upward mobility in the social status of the giver by means of conspicuous generosity rather than conspicuous consumption.

Some of the richest people in the world enact their identities as philanthropists via altruistic endeavors. These social investors are running transformative organizations that are part of an emerging phenomenon named "philanthrocapitalism" (Bishop and Green, 2008). This term describes the "growing recognition by the leaders of capitalism that giving back much of their fortune to improve society is much a part of the system as making money in the first place" (Bishop and Green, 2008, p. xii). Furthermore, world-class celebrities appear in the mass media revealing their humanitarian side. For people with higher status in society, philanthropy may be a way to fit in rather to stand out, a way to conform the norm "noblesse oblige" and not entirely a voluntary act. Since individuals from the upper class are showing an altruistic behavior, consumers from lower classes may mimic this behavior in a quest to gain status in society (Veblen, 1994/1899).

\section{Managerial implications}


Jafari (2013, p. 4) asserts that "we have failed to make effective use of markets and marketing for the betterment of human life in general." This statement may come as a surprise in an age where corporate social responsibility is the rule rather than the exception for many businesses (Murphy and Schlegelmilch, 2013; Torelli, Monga, and Kaikati, 2011). While acknowledging this situation, Jafari (2013) calls for collective social responsibility rather corporate, which resonates with the voices of the informants. Corporate leaders have not been elected, nor do they necessarily have the expertise, to ameliorate the well-being of society. They depend on consumers and governments to crave for social enterprise in order to create a humanistic society which measures its performance based on the width of its citizens' smiles instead of the size of their pockets (ibid.). According to the findings, this interest in the collective smiles has spread its seeds in current consumer culture, and notably, without necessarily any tradeoff between the interest in collective and personal smiles. The informants believe that collective smiles - set off by personal generosity- can create instant personal smiles, trickle forward, and create a spiral of good, which, in turn, changes society and themselves. This proposition requires an inclusive approach from consumers, companies, NGOs, educational and public institutions, widening their horizon to being not only prosocial but being pro-humanity. In the following, the article underlines the implications of the findings for these agents:

\subsection{Companies adopting a philanthropic approach}

First of all, in recent years the business world has witnessed how CSR initiatives have gotten more space in the business agenda. However, they are still pushed into the background, not taking a protagonist role. Previous research on consumer identity shows that consumers prefer brands whose identity matches their own identity (Bhattacharjee, Berger, and Menon, 2014). According to this idea, consumers who align with the informants' perception of luxury will show a preference for brands contributing significantly to altruistic 
causes. Similarly, recent research by Chernev and Blair (2015) report that companies who truly engage in socially responsible activities (e.g., philanthropic giving), driven by benevolence rather than self-interest reap the benefit of not only having a positive impact on the company's reputation but also on consumer perceptions of product performance. Drawing from the four types of social responsibilities of businesses, that is, economic, legal, ethical, and philanthropic (Carroll, 1979), this implication puts clear emphasis on the latter and implies that the philanthropic component of CSR requires increased attention.

Second, besides offering consumers the role of social activists by making philanthropic consumption choices, companies may also consider to do so by offering philanthropic career choices. Some informants perceive having a job which allows them to make a meaningful contribution to humankind as a luxury. In addition, Grant, Dutton, and Rosso (2008) assert that employees establish stronger bonds and higher levels of commitment with companies with active corporate volunteering programs. Thus, managers may consider a redefinition of the corporate objectives in order to match the quest for making the meaningful contributions that individuals are claiming. "Just Better Jobs" is an example of such a corporate philosophy. This company is targeting people who consider making a difference a key issue in their careers, by "connecting job-seekers directly with for-profit companies that share their commitment to positive social and environmental change" (Just Better Jobs, 2014).

The informants place making significant contributions in the realm of luxury and in a desirable and aspirational scenario, which involves that they might not be accessible for them. However, triggering positive transformations in the lives of those in dire need may be easier to achieve for powerful companies than for individual consumers, which means that companies and consumers can join forces in co-constructing societal change when brands that pursue this transformative objective are available to and preferred by consumers and 
employees. Thus, companies may benefit from adopting a philanthropic approach and marketing managers can decide to communicate the company's philanthropic endeavors in order to engage with consumers and employees who highly value them.

\subsection{Companies born with philanthropy at their heart}

Rather than adopting a philanthropic approach when they are mature companies, some firms have been born under the idea of making a difference for the "family of mankind". "Les Deux," a Danish fashion brand, follows this idea by teaming up with consumers in order to transform the lives of children in Zambia. The company explains its philosophy as follows: "The time has come where it is our turn to give back to those in need. Even though we are a small company we believe that we make a difference. So, we are building a school in Zambia and making sure that the kids have what they need in order to educate themselves and create a better future. Every time you buy an item from Les Deux we will give a child at the school a fresh t-shirt and make sure that all students at the school have a school kit when they start -including everything from pencils to malaria vaccine. (..) As we always say -A family-" (Les Deux, 2014).

This example illustrates the merger of entrepreneurship and philanthropy, which are increasingly intertwined in a new generation of business that have a transformative approach as part of their DNA. In this vein, Chandy $(2015$, p. 1) asserts that a movement called philanthropreneurship is gaining protagonism. According to this author, "the philanthropreneur business model involves working donations of time, effort, and money into the very core of how a business operates," which mirrors the transformative agents in the informants' view of luxury. This approach opens a new world of opportunities for a new generation of start-up companies with a transformative approach at their heart, working hand in hand with consumers to co-create a difference in the lives of those in need. Bearing in 
mind that consumers conforming with generation G's values replace greed with generosity as the pivotal aspect in the business and societal mindset (Trendwatching, 2009), generosity may act as the connector linking consumers and companies in a common endeavor to beget impactful transformations in the lives of non-related others and meaningful social change while boosting a shift from corporate social responsibility to collective social responsibility.

\subsection{Philanthropy in non-profit organizations and educational institutions}

The findings also imply that non-profit organizations might consider widening their horizon. The results of this study point at a qualitative rather than quantitative shift in the sharing out phenomenon. The fact that consumers can feel so strongly about sharing out that this ethos becomes a personal luxury to them means that social marketers and charities may want to address pro-social consumer behavior differently in the future than they have done so far. Traditionally, charities have asked consumers to contribute to social causes mainly through monetary contributions (affordable to them). By allowing and fostering consumers to engage in social projects on a deeper level, giving them the opportunity of engaging in meaningful experiences, making a difference, by sharing their social or cultural capital, not just as external agents but as active change makers may enhance the collaboration of some consumers with the non-for-profit sector.

This transformative approach is also emerging in the educational system. An example of this is the University of South Carolina which offers a master of science in social entrepreneurship with the following claim: "changing the world, that's your business" and explicitly states that if you enroll in this master "you will balance your head and heart as you embark on a career with meaning and attack the most pressing global challenges [...]. Make an impact in areas including poverty alleviation, healthcare, gender equity, education and the environment. Bring more meaning to your career in the private sector" (USC Marshall, 2014, 
p. 1). Along the same lines, ever since 2007 the London Business School has co-hosted, with the Stars Foundation, the Philanthropreneurship Forum, an event turning the spotlight toward an entrepreneurial approach to philanthropy. They specifically state that "it is giving that disrupts the status quo" (Philanthropreneurship Forum, 2015, p. 1).

\subsection{Philanthropy in consumer society}

Chandy (2015) asserts that the concept of philanthropreneurship is not restricted to the corporate world. Instead, this approach covers a wide array of agents including corporate leaders, political figures, celebrities, for-profit companies, non-profit organizations, and academic institutions. They all share the following traits: "passion to make life better for others; willingness to give, in money, ideas, and/or time; ingenuity to envision new approaches to solving problems; leadership and the ability to direct, organize, and influence the efforts of others" (Chandy, 2015, p. 1).

The dominant values in the consumer society revolve around competition, individualism, growth, greed and hierarchy (Mathur, 2014, p. 135), erecting an invisible wall separating us (me and my close group) from distant others. As a counter-reaction -or perhaps even rebellion- toward this individualization and disenchantment in consumer society, consumers may increasingly act as postmodern tribalists seeking connection rather than consumption per se, relegating the use of the object consumed to a secondary position and bringing the linking value to the fore (Cova, 1997). The results of the analysis show that some consumers find playing an interventionist role in society and being part of the philanthropreneurs community to be a luxury. As the authors have illustrated, this consumer quest can be addressed by companies, non-profit organizations, and educational, and public institutions, in different ways, all sharing the idea of a co-creative, collective endeavor for the common good. 
Also, since sharing inspires others to do good, well-being may spread and change the social surroundings of the giver. For example, research shows that generosity can spread by three degrees, from giver to recipient and from recipient to the next recipient (Christakis and Fowler, 2009). Ultimately, this dynamic implies that sharing out leads to both individual and collective well-being (cf. Belk and Llamas, 2011).

Finally, the academic community plays a key part in leading transformations in society, inspiring and empowering different stakeholders to not settle to uneventful and meaningless roles in the society but instead search for purpose, make a social impact, and encourage purposeful lives. If academia succeeds in this pursuit, society will witness a democratization of the luxury of achieving meaning by making significant contributions to the lives of others, as well as the transformation of an industrial growth society into a lifesustaining society (Macy and Brown, 1998). The authors hope to have contributed to ignite this change by giving voice to a pro-social, pro-ego, and pro-humanity consumer perspective that, they believe, is new to the arena of luxury. 


\section{References}

Aaker, L., \& Akutsu, S. (2009). Why do people give? The role of identity in giving. Journal of Consumer Psychology, 19, 267-270.

Achabou, M. A., \& Dekhili, S. (2013). Luxury and sustainable development: Is there a match? Journal of Business Research, 66, 1896-1903.

Aknin, L. B., Barrington-Leigh, C. P., Dunn, E. W., Helliwell, J. F., Burns, J., BiswasDiener, R., Kemeza, I., Nyende, P., Ashton-James, C. E., \& Norton, M. I. (2013). Prosocial spending and well-being: Cross-cultural evidence for a psychological universal. Journal of Personality and Social Psychology, 104(4), $635-652$.

Alvesson, M., \& Sköldberg, K. (1994). Tolkning och reflektion. Lund: Studentlitteratur.

Andreoni, J. (1989). Giving with impure altruism: Applications to charity and Ricardian equivalence. Journal of Political Economy, 97, 1447-1458.

Appadurai, A. (1986). Introduction: Commodities and the politics of value. In A . Appadurai (ed.), The social life of things: Commodities in cultural perspective. Cambridge: Cambridge University Press, 3-63.

Atwal, G., \& Williams, A. (2009). Luxury brand marketing -The experience is everything! Journal of Brand Management, 16(5), 338-346.

Ball, M. S., \& Smith, G.W. H. (1992). Analyzing visual data. Qualitative research series. Newbury Park: Sage.

Batson, C. D., \& Shaw, L. L. (1991). Evidence for altruism: Toward a pluralism of prosocial motives. Psychological Inquiry, 2(2), 107-122. 
Bauer, M., von Wallpach, S., \& Hemetsberger, A. (2011). 'My little luxury': A consumercentered, experiential view. Marketing ZFP - Journal of Research and Management, 33 (January), 57-68.

Bekkers, R., \& Wiepking, P. (2007). Generosity and philanthropy: A literature review. Report commissioned by the John Templeton Foundation. Available at SSRN: http://ssrn.com/abstract=1015507 (accessed Nov. 20th, 2014).

Bhattacharjee, A., Berger, J. \& Menon, G. (2014). When identity marketing backfires: Consumer agency in identity expression. Journal of Consumer Research, 41(2), 294-309.

Belk, R. W. (1985). Materialism: Traits aspects of living in the material world. Journal of Consumer Research, 12(3), 265-280.

Belk, R. W. (1988). Possessions and the extended self. Journal of Consumer Research, 15(2), $139-168$.

Belk, R. W. (2007). Why not share rather than own? Annals of the American Academy of Political and Social Science, 611(May), 126-140.

Belk, R. W. (2010). Sharing. Journal of Consumer Research, 36(5), 715-734.

Belk, R. W. (2014). You are what you can access: Sharing and collaborative consumption online," Journal of Business Research, 67(80), 1595-1600.

Belk, R. W., \& Coon, G.S. (1993). Gift giving as agapic love: An alternative to the exchange paradigm based on dating experiences. Journal of Consumer Research, 20(3), $393-417$. 
Belk, R. W., Kimura, J., \& Tanaka, H. (2007). The luxury value pyramid: What are the dimensions of luxury? Distributed with Michael Solomon, Consumer behavior: Buying, having, and being, 8th edition.

Belk, R. W., \& Llamas, R. (2011). The nature and effects of sharing in consumer behavior. In D. G. Mick, D.G., S. Pettigrew, C. Pechmann, \& J. L. Ozanne (eds.). Transformative consumer research for personal and collective well-being. New York: Taylor \& Francis, 625-646.

Belk, R. W., \& Llamas, M. R. (2013). Shared possessions and shared self. In R. W. Belk, R.W. \& A. Ruvio (eds.). The Routledge Companion to Identity and Consumption. London: Routledge, 265-72.

Belk, R.W., Wallendorf, M., \& Sherry, J. F. Jr. (1989). The sacred and the profane in consumer behavior: Theodicy on the odyssey. Journal of Consumer Research, 16(June), 1-38.

Bem, D. J. (1967). Self-perception: An alternative interpretation of cognitive dissonance phenomena. Psychological Review, 74(3), 183-200.

Bem, D. J. (1972). Self-perception theory. In L. Berkowitz (Ed.). Advances in Experimental Social Psychology, Vol. 6. New York: Academic Press, 1-62.

Benkler, Y. (2004). Sharing nicely: On shareable goods and the emergence of sharing as a modality of economic production. Yale Law Journal, 114(November), 273-358.

Berry, C. J. (1994). The idea of luxury. A conceptual and historical investigation. Cambridge: Cambridge University Press. 
Beverland, M. (2005). Crafting brand authenticity: The case of luxury wines. Journal of Management Studies, 42(5), 1003-1029.

Bishop, M., \& Green, M. (2008). How the rich can save the world: Philanthrocapitalism. New York: Bloomsbury.

Boone, James L. (1998). The evolution of magnanimity: When is it better to give than to receive? Human Nature, 9(1), 1-21.

Bourdieu, P. (1983). Forms of capital. In J. C. Richards (ed.). Handbook of theory and research for the sociology of education. New York: Greenwood Press, 241-58.

Bourdieu, P. (1984). Distinction: A social critique of the judgement of taste. London: Routledge.

Carroll, A.B. (1979). A Three-dimensional Conceptual Model of Corporate Social Performance. Academy of Management Review, 4, 4, 497-505.

Cavender, R. C. \& Kincade, D. H. (2014). Management of a luxury brand: dimensions and sub-variables from a case study of LVMH. Journal of Fashion Marketing and Management, 18(2), 231-248.

Chandy, R. (2015). Here Come the Philanthropreneurs. Fast Coexist. Available at: http://www.fastcoexist.com/3044343/here-come-the-philanthropreneurs (accessed April 23rd, 2015).

Cheal, D. (1988). The gift economy. New York: Routledge. 
Chernev, A. \& Blair, S. (2015). Doing Well by Doing Good: The Benevolent Halo of Corporate Social Responsibility. Journal of Consumer Research, 41(6), 14121425 .

Chevalier, M., \& Mazzalovo, G. (2008). Luxury brand management. A world of privilege. Singapore: Wiley.

Choi, S. (2003). The effects of the perceived product characteristics and conspicuous consumption on the fashion luxury involvement. Journal of the Korean Society of Clothing and Textiles, 27(2), 209-218.

Christakis, N. A. \& Fowler, J. H. (2009). Connected: The surprising power of our social networks and how they shape our lives, New York: Little, Brown and Co.

Christodoulides, G., Michaelidou, N., \& Li, C. H. (2009). Measuring perceived brand luxury an evaluation of the BLI scale. Journal of Brand Management, 16, 395-405.

Clark, M. S., \& Mills, J. (1993). The difference between communal and exchange relationships: What it is and is not. Personality and Social Psychology Bulletin, 19, 684-691.

Corbin, J. M., \& Strauss, A. C. (2008). Basics of qualitative research: Techniques and procedures for developing grounded theory, 3rd ed. Thousand Oaks, CA: Sage.

Cova, B. (1997). Community and consumption: Towards a definition of the "linking value" of product or services. European Journal of Marketing, 31(3/4), 297-316.

Derrida, J. (1992). Donner la Mort. In J. M. Rabate \& M. Wetzel (eds.). L'e'thique du don: Jacques Derrida et la pense'e du don. Paris, France: Mé tailie-Transition. 
Dhar, R., \& Wertenbroch, K. (2000). Consumer choice between hedonic and utilitarian goods. Journal of Marketing Research, 37 (February), 60-71.

Douglas, M., \& Isherwood, B. (1979). The world of goods: Towards an anthropology of consumption. New York: W.W. Norton.

Dubois, B., \& Duquesne, P. (1993). The market for luxury goods: Income versus culture. European Journal of Marketing, 27(1), 35-45.

Dubois, B., Laurent, G., \& Czellar, S. (2001). Consumer rapport to luxury: Analyzing complex and ambivalent attitudes. Working paper, HEC.

Dubois, B., \& Paternault, C. (1995). Observations: Understanding the world of international luxury brands: The 'dream formula'. Journal of Advertising Research, 35(4), 69-76.

Dunn, E. W., Aknin, L. B., \& Norton, M. I. (2008). Spending money on others promotes happiness. Science, 319(5870), 1687-1688.

Fionda, A. M., \& Moore, C. M. (2009). The anatomy of the fashion luxury brand. Journal of Brand Management, 16(5-6), 347-363.

Freire, N. A. (2014). When luxury advertising adds the identitary values of luxury: A semiotic analysis. Journal of Business Research, 67, 2666-2675.

Goodwin, N. R., Ackerman, F., \& Kiron, D. (eds.) (1997). The consumer society. Washington, DC: Island Press. 
Grant, A. M., Dutton, J. E. \& Rosso, B. D. (2008), Giving Commitment: Employee Support Programs and the Prosocial Sensemaking Process. Academy of Management Journal, 51(5), 898-918.

Groth, J. C., \& McDaniel, S. W. (1993). The exclusive value principle. Journal of Consumer Marketing, 10(1), 10-16.

Hardy, C. L., \& Van Vugt, M. (2006). Nice guys finish first: The competitive altruism hypothesis. Personality and Social Psychology Bulletin, 32, 1402-1413.

Hemetsberger, A., Hoppe, M., Matzler, K., Mühlbacher, C., \& Pichler, E. A. (2010). Sensing and experiencing the transformative power of private brands - An investigation into passionate consumption of lingerie. In Proceedings of the 39th EMAC conference, Copenhagen, CD-ROM.

Hladká, M. (2009), Philanthropy: Integral Part of the Economic as well as Social Theories. In European graduate school for social sciences, $14^{\text {th }}-17^{\text {th }}$ of May, Telč, Czech Republic.

Hoe, L., Hogg, G., \& Hart, S. (2003). Fakin’ it: Counterfeiting and consumer contradictions. In D. Turley \& S. Brown (eds.). European Advances in Consumer Research. Association for Consumer Research, 60-67.

Hoppe, M., Hemetsberger, A., Pichler, E., \& Matzler, K. (2009). The transformative power of brands - an investigation into the impact of self- transformation on consumer passion. Proceedings of the 38th EMAC Conference, Nantes.

Jafari, A. (2013). Can society nurture humanistic marketing. In R. Varey \& M. Prison (Eds.). Humanistic Marketing. London: Palgrave Macmillan, 113-125. 
Jäckel, M. \& Kochhan, C. (2000). Notwendigkeit und Luxus: Ein Beitrag zur Geschichte des Konsums. Leske + Budrich, Opladen, 73-93.

Just Better Jobs (2014). About us. Available at: http://www.justbetterjobs.com/about-us/ (accessed Nov. 20th, 2014).

Kastanakis, M. N. \& Balabanis, G. (2014). Explaining variation in conspicuous luxury consumption: An individual differences' perspective. Journal of Business Research, 67, 2147-2154.

Kapferer, J.-N. (1997). Managing luxury brands. Journal of Brand Management, 4(4), 251 60.

Kapferer, J.-N. (2008), The new strategic brand management: Creating and sustaining brand equity long term, 4th ed. London: Kogan Page.

Kapferer, J.-N. \& Bastien, V. (2012), The luxury strategy: Break the rules of marketing to build luxury brands, $2^{\text {nd }}$ ed. London: Kogan Page.

Kauppinen, A. (2013). Meaning and happiness. Philosophical Topics, 41(1), 161-85.

Keller K. L. (2009). Managing the growth trade-off: Challenges and opportunities in luxury branding. Journal of Brand Management, 16, 290-301.

Lepper, M. R., Greene, D., \& Nisbett, R. E. (1973). Undermining children's intrinsic interest with extrinsic reward: A test of the 'overjustification' hypothesis. Journal of Personality and Social Psychology, 28(1), 129-37.

Les Deux (2014). L2 Project. Available at: http://www.lesdeux.dk/content/7-12-project (accessed Nov. 20th, 2014). 
Lipovetsky, G. (2003). El lujo eterno: De la era de lo sagrado al tiempo de las marcas. Barcelona: Anagrama.

Luedicke, M. K., Thompson, C. J., \& Giesler, M. (2010). Consumer identity work as moral protagonism: How myth and ideology animate a brand-mediated moral conflict. Journal of Consumer Research, 36(6), 1016-33.

Lyubomirsky, S. (2008). The how of happiness: A scientific approach to getting the life you want. London: Penguin books.

Macy, J., and Brown, M. Y. (1998). Coming back to life: Practices to reconnect our lives, our world. Gabriola Island, BC: New Society Publishers.

Mandeville, B. (1732). The fable of the bees: Or, private vices, public benefits. Sixth edition. London: J. Tonson.

Mathur, N. (2014), Consumer culture, modernity, and identity. London: Sage.

Mauss, M. (1954). The gift: Forms and functions of ex-change in archaic societies. London: Cohen \& West.

McCracken, G. (1988). The long interview. Newbury Park, CA, USA: Sage.

Megehee, C. M., \& Spake, D. F. (2012). Consumer enactments of archetypes using luxury brands. Journal of Business Research, 65, 1434-1442.

Miller, K. W., \& Mills, M. K. (2012). Contributing clarity by examining brand luxury in the fashion market. Journal of Business Research, 65, 1471-1479.

Mortelmans, D. (2005). Sign values in processes of distinction: The concept of luxury. Semiotica, 157(1-4), 497-520. 
Murphy, P. E., \& Sclegelmilch, B. B. (2013). Corporate social responsibility and corporate social irresponsibility: Introduction to a special topic section. Journal of Business Research, 66, 1807-1813.

Nia, A., \& Zaichkowsky, J. L. (2000). Do counterfeits devalue the ownership of luxury brands? Journal of Product and Brand Management, 9(7), 485-497.

Noble, C. H., \& Walker, B. A. (1997). Exploring the relationships among liminal transitions, symbolic consumption, and the extended self. Psychology and Marketing, 14(1), 29-47.

Lloyd, T. (2004). Why rich people give. London: Association of Charitable Foundations.

O'Cass A., \& McEwen, E. (2004). Exploring consumer status and conspicuous consumption. Journal of Consumer Behavior, 4(1), 25-39.

Okonkwo U. (2007). Luxury fashion Branding: Trends, Tactics, Techniques. Basingstoke, Hampshire UK: Palgrave Macmillan.

Pantzalis, I. (1995). Exclusivity strategies in pricing and brand extension. Unpublished doctoral dissertation. Tucson, AZ: University of Arizona.

Phau, I., \& Prendergast, G. (2000). Consuming luxury brands: The relevance of the 'rarity principle'. Journal of Brand Management, 8 (2), 122-138.

Philanthropreneurship Forum (2015). The name. Available at: https://www.philanthropreneurshipforum.com/the-forum.php (accessed Nov. 20th, 2014). 
Plotkin, B. (2008). Nature and the human soul: Cultivating wholeness and community in a fragmented world. Novato, CA: New World Library.

Poddar, A., Foreman, J., Banerjee, S., and Ellen, P. S. (2012). Exploring the Robin Hood effect: moral profiteering motives for purchasing counterfeit products. Journal of Business Research, 65, 1500-1506.

Postrel, V. (2008). Inconspicuous consumption: A new theory of the leisure class. The Atlantic, http://www.theatlantic.com/magazine/archive/2008/07/inconspicuousconsumption/306845/ (accessed Nov. 20th, 2014).

Roberts, G. (1998). Competitive altruism: From reciprocity to the handicap principle. Proceedings of the Royal Society, 265, 427-431.

Scaife, W., McDonald, K. \& Smyllie, S. (2011). A Transformation Role. Donor and Charity Perspectives on Mayor Giving in Australia. Queensland: Australian Centre for Philanthropy and Nonprofit Studies, Queensland University of Technology.

Schnell, T. (2009). The sources of meaning and meaning in life questionnaire (SoMe): Relations to demographics and well-being. Journal of Positive Psychology, 4(6), 483-499.

Schouten, J. W. (1991). Selves in transition: Symbolic consumption in personal rites of passage and identity reconstruction. Journal of Consumer Research, 17(4), 412425.

Schulz, J. (2006). Vehicle of the self. The social and cultural work of the H2 Hummer. Journal of Consumer Culture, 6(1), 57-86. 
Sekora, J. (1977). Luxury: the concept in Western Thought, Eden to Smollet. London: John Hopkins University Press.

Seligman, M. E. P (2011). Flourish: A visionary new understanding of happiness and wellbeing. New York: Free Press.

Sherry, J., McGrath, M., \& Levy, S. (1995). Egocentric consumption: Anatomy of gifts given to self. In J. Sherry (Ed.). Contemporary Marketing and Consumer Behavior: An Anthropological Sourcebook. New York: Sage, 339-432.

Shukla, P. (2011). Impact of interpersonal influences, brand origin and brand image on luxury purchase intentions: Measuring interfunctional interactions and a crossnational comparison. Journal of World Business, 46(2), 242-253.

Sombart, W. (1922). Liebe, Luxus und Kapitalismus. Berlin: Wagenbach.

Thompson, C. J. (1997). Interpreting consumers: A hermeneutical framework for deriving marketing insights from the texts of consumers' consumption stories. Journal of Marketing Research, 34, 438-455.

Thompson, C. J., \& Hirschman, E. C. (1995). Understanding the socialized body: A poststructuralist analysis of consumers' self-conceptions, body images, and selfcare practices. Journal of Consumer Research, 22 (2), 139-153.

Thompson, C. J., Locander, W. B. \& Pollio, H. R. (1989), Putting Consumer Experience Back into Consumer Research: The Philosophy and Method of ExistentialPhenomenology, Journal of Consumer Research, 16 (September), 133-146.

Thompson, C.J., Pollio, H. R., \& Locander, W. B. (1994). The spoken and the unspoken: A hermeneutic approach to understanding the cultural viewpoints that underlie 
consumers' expressed meanings. Journal of Consumer Research, 21(3), 432452.

Thomsen, T. U., \& Sørensen, E. B. (2006). The first four-wheeled status symbol. Pram consumption as a vehicle for the construction of motherhood identity. Journal of Marketing Management, 22(9-10), 907-927.

Tidwell, P., \& Dubois, B. (1996). A cross-cultural comparison of attitudes toward the luxury concept in Australia and France. In R. W. Belk \& R. Groves (eds.). Asia Pacific Advances in Consumer Research. Association for Consumer Research, 31-35.

Torelli, C. J., Monga, A. B., \& Kaikati, A. M. (2011). Doing poorly by doing good: Corporate social responsibility and brand concepts. Journal of Consumer Research, 38(5), 948-963.

Toynbee, P., \& Walker, D. (2008). Unjust rewards: Exposing greed and inequality in Britain today. London: Granta.

Trendwatching (2009). Generation G. That would b 'G' for generosity, not “G” for greed. Available at: http://trendwatching.com/trends/generationg/ (accessed Nov. 20th, 2014).

Truong Y., Simmons G., McColl, R., \& Kitchen P.J. (2008), Status and conspicuousness Are they related? Strategic marketing implications for luxury brands. Journal of Strategic Marketing,16(3),189-203.

Twitchell, J. B. (2002). Liviting it up: America's love affair with luxury. New York: Columbia University Press. 
Tynan, C., McKechnie, S., \& Chhuon, C. (2010). Co-creating value for luxury brands. Journal of Business Research, 63(11), 1156-1163.

USC Marshall (2014), Master of Science in Social Entrepreneurship. Available at: http://www.marshall.usc.edu/msse (accessed Nov. 20th, 2014).

Veblen, T. (1994/1899). The theory of the leisure class. New York: Penguin Classics, (First published, 1899, New York: MacMillan).

Vickers, J.S. \& Renan, F. (2003). The marketing of luxury goods: An exploratory study Three conceptual dimensions. The Marketing Review, 3 (4), 459-478.

Vigneron, F., \& Johnson, L. (2004). Measuring perceptions of brand luxury. Journal of Brand Management, 11(6), 484-506.

Walley, K., Custance, P., Copley, P. \& Perry, S. (2013). The key dimensions of luxury from a UK consumers' perspective. Market Intelligence and Planning, 31(7), 823-837.

Wiedmann, K., Hennigs, N., \& Siebels, A. (2007). Measuring consumers‘ luxury value perception: A cross-cultural framework. Academy of Marketing Science Review, $7,1-23$.

Wiedmann, K., Hennigs, N. \& Siebels, A. (2009). Value-based segmentation of luxury consumption behavior. Psychology and Marketing, 26, 7, 625-651.

Winterich, K. P., Mittal, V., \& Aquino, K. (2013). When Does Recognition Increase Charitable Behavior? Toward a Moral Identity-Based Model. Journal of Marketing, 77(3), 121-134. 
Wong, N. Y., \& Ahuvia, A. (1998). Personal taste and family face: Self-concepts and luxury consumption in confucian and western societies. Psychology and Marketing, $15(5), 423-441$.

Ye, N., Teng, L., Yu, Y., \& Wang, Y. (2015). "What's in it for me?”: The effect of donation outcomes on donation behavior. Journal of Business Research, 68(3), 480-486.

Table 1. The given, the recipients, and the informants

\begin{tabular}{|c|c|c|c|}
\hline Type of giving & What is given & To whom & Informant \\
\hline Donation & $\begin{array}{l}\text { Endowment for a gallery } \\
\text { which carries cultural } \\
\text { heritage goods }\end{array}$ & $\begin{array}{l}\text { for other people to see } \\
\text { and enjoy }\end{array}$ & $\begin{array}{l}\text { (Christian, M61, } \\
\text { UK) }\end{array}$ \\
\hline Donation & $\begin{array}{l}\text { Economic resources for } \\
\text { different causes }\end{array}$ & $\begin{array}{l}\text { related to children, poor } \\
\text { people }\end{array}$ & (Nathan, M37, UK) \\
\hline Donation & $\begin{array}{l}\text { Economic resources for } \\
\text { different causes related to } \\
\text { schools, hospitals and } \\
\text { nursing homes }\end{array}$ & $\begin{array}{l}\text { children, ill people, } \\
\text { elderly }\end{array}$ & (Ragnar, M59, SW) \\
\hline Adoption & $\begin{array}{l}\text { Economic and time } \\
\text { resources }\end{array}$ & starving children & (Edu, M31, SP) \\
\hline Adoption & $\begin{array}{l}\text { Economic and time } \\
\text { resources }\end{array}$ & an ill-fated child & (Gretel, F38, GE) \\
\hline Taking care & Time resources & $\begin{array}{l}\text { children who have no } \\
\text { place to go or parents } \\
\text { who are not functioning }\end{array}$ & (Eva, F50, SW) \\
\hline Volunteering & $\begin{array}{l}\text { Knowledge and time } \\
\text { resources devoted to } \\
\text { teaching English and saving } \\
\text { animals in the rainforest }\end{array}$ & $\begin{array}{l}\text { poor children } \\
\text { animals }\end{array}$ & (Edita, F26, GE) \\
\hline $\begin{array}{l}\text { Promoting a } \\
\text { good cause }\end{array}$ & $\begin{array}{l}\text { Economic and social } \\
\text { resources to widen access to } \\
\text { education }\end{array}$ & children & (Mar, F25, SP) \\
\hline $\begin{array}{l}\text { Work for a } \\
\text { charity }\end{array}$ & $\begin{array}{l}\text { Time resources devoted to } \\
\text { helping people improve } \\
\text { their quality of life }\end{array}$ & less fortunate people & (Kajsa, F29, SW) \\
\hline $\begin{array}{l}\text { Making } \\
\text { conscious (and }\end{array}$ & $\begin{array}{l}\text { Economic resources to } \\
\text { enable more environmental }\end{array}$ & environment & (David, M42, UK) \\
\hline
\end{tabular}




\begin{tabular}{|l|l|l|l|}
\hline $\begin{array}{l}\text { more } \\
\text { expensive) } \\
\text { consumption } \\
\text { choices }\end{array}$ & $\begin{array}{l}\text { friendly consumption } \\
\text { choices, like buying an } \\
\text { electric car }\end{array}$ & & \\
\hline $\begin{array}{l}\text { Making } \\
\text { conscious (and } \\
\text { more } \\
\text { expensive } \\
\text { consumption } \\
\text { choices) }\end{array}$ & $\begin{array}{l}\text { Economic resources to } \\
\text { enable more sustainable } \\
\text { consumption choices, like } \\
\text { pursuing an eco-friendly } \\
\text { lifestyle }\end{array}$ & $\begin{array}{l}\text { future generations and } \\
\text { the environment }\end{array}$ & (Henrike, F25, GE) \\
\hline
\end{tabular}

